mansasa

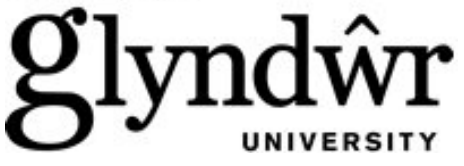

Glyndŵr University

Glyndŵr University Research Online

Theology

Theology

$1-1-2000$

\title{
The "initial evidence": implications of an empirical perspective in a British context
}

William K. Kay

Glyndwr University, w.kay@glyndwr.ac.uk

Follow this and additional works at: http://epubs.glyndwr.ac.uk/theo

Part of the Religious Thought, Theology and Philosophy of Religion Commons

This is an electronic version of an article that was first published in the Journal of the European

Pentecostal Theological Association in 2000. The journal website is available at

http://www.eptaonline.com/

\section{Recommended Citation}

Kay, W. K. (2000) 'The "initial evidence”: implications of an empirical perspective in a British context'. Journal of the European Pentecostal Theological Association 20, 25-31

This Article is brought to you for free and open access by the Theology at Glyndŵr University Research Online. It has been accepted for inclusion in Theology by an authorized administrator of Glyndŵr University Research Online. For more information, please contact d.jepson@glyndwr.ac.uk. 


\title{
The 'initial evidence': implications of an empirical perspective in a British context
}

\author{
Revd Professor William K Kay, Glyndwr University
}

\section{INTRODUCTION}

This paper addresses three questions. Each concerns the Elim Pentecostal Church (hereafter abbreviated to Elim) and Assemblies of God in Great Britain and Ireland (hereafter abbreviated to British Assemblies of God). First, what do Elim and British Assemblies of God ministers believe about the evidence, whether initial or otherwise, for the baptism in the Holy Spirit? Second, in the light of what empirical evidence shows them to believe, how closely do these ministers adhere to their denomination's fundamental truths? Third, what are the implications of these findings for any possible organisational combination between the Elim and British Assemblies of God?

These three questions are interwoven within the historical development of the two denominations as the following considerations show.

From their respective inceptions in 1915 and 1924 Elim and British Assemblies of God have hesitated on the brink of combination. The conference in May 1924 at which British Assemblies of God for the first time called together its pastors and elders met, on the second day of its deliberations, George Jeffreys and a delegation from the Elim Evangelistic Band (as it was then called). The proposal to the conference that the Elim contingent become the evangelistic arm of a combined Pentecostal fellowship was received and recognised as a bold initiative that, in the end, came to nothing because powerful voices, notably Howard Carter's, thought Pentecostalism in Britain would be risking its future by putting all its resources into a single organisation ${ }^{1}$.

Subsequent suggestions that the two denominations work together more closely were also made after a Unity Conference 'to seek to find a basis for unity without compromising any vital truths' was held in London in 1939. In 1948 fourteen leaders from five British Pentecostal groups met for two days in London and issued a joint statement (Kay, 1989: 205). The two largest of the groups were Elim and Assemblies of God and they helped to form the British Pentecostal Fellowship whose doctrinal statement included the rubric 'we believe in the baptism in the Holy Spirit with supernatural evidence and in the gifts of the Spirit'.

The lack of specificity was deliberate. It allowed the Elim and Assemblies of God positions to be subsumed within the same form of words.

In 1922 the Elim constitutional position was that 'the Holy Ghost, which is the promise of God, is accompanied by speaking in other tongues as the Spirit gives utterance'. In 1934 this position was changed to reflect the Foursquare Gospel and the relevant words were, 'we believe that our Lord Jesus Christ is the Baptiser in the Holy Ghost, and that this Baptism

\footnotetext{
${ }^{1}$ A letter from George Jeffreys to Howard Carter (28th June, 1926) discusses the constitutional basis for unity between the two denominations. The letter is held in the interdenominational Donald Gee Centre for Pentecostal and Charismatic Research at Mattersey Hall.
} 
with signs following is promised to every believer'. This position remains in current force. In essence it asserts a baptism in the Holy Spirit [Ghost] given by Christ and evidenced by 'signs following', that is, some form of physical manifestation - usually but not necessarily tongues.

The British Assemblies of God position was built into the Statement of Fundamental Truths it had adopted in 1924 and which appears from its phraseology and the order of its subject matter to have been strongly influenced by the similar doctrinal statement adopted by Assemblies of God in the United States in 1916 (Kay, 1997). It has remained almost entirely unchanged since that time. The current British Assemblies of God Statement of Fundamental Truths says 'We believe in the baptism in the Holy Spirit, the initial evidence of which is the speaking with other tongues as the Spirit gives utterance. Acts 2.4; 10.44-46; 11.14-16; 19.6; Isa 8.18 '.

In October 1963 a joint meeting took place between representatives of Elim and Assemblies of God with a view to a possible merger. The discussion broke down over the single word 'initial'. As Alex Tee, one of the participants in the discussion, explained to me 'speaking with tongues was, for Elim, the "invincible evidence" because someone filled with the Spirit might prophesy rather than speak in tongues, or prophesy before speaking in tongues' (Kay, 1989: 285, original emphasis). Yet, despite the failure of the discussions to produce any concrete results, Elim and British Assemblies of God continued to work together both by instituting regular joint meetings between their Executive Councils and through shared General Conferences, most recently at Bognor in 1996 and again in 1997. These Conferences retained separate business sessions, but in other respects were unified.

As far as the theology of the baptism in the Spirit was concerned McGee (1991) points out the British Assemblies of God position was defended and expounded consistently by its leading ministers, notably Donald Gee and Harold Horton. Elim writers often accepted the same position without difficulty (for example Walker, 1976: 34), though others entered reservations. Canty (1987: 84) argued that 'I do not think it logical to say that tongues are the initial evidence of the Baptism, because some tongues are unreal' but he went on to add, 'nevertheless I do not accept that in normal experience there is a true Baptism without speaking in tongues' (original emphasis).

As a practical matter concerning the beliefs of ministers it needs to be noted that British Assemblies of God ministers are only required to give formal assent to fundamental denominational doctrinal truths once, that is, at the point when they first apply for accreditation $^{2}$. The same is true of Elim ministers. Despite what appears to be the looseness of this system for ensuring doctrinal conformity, the annual General Conferences of both fellowships are rarely occasions for deep-seated doctrinal disagreement. Where there is a threat of this (as for example occurred over understanding of the millennium, (Allen, 1987)), it is normally sufficient for the position incorporated within the fundamental truths to be restated through a seminar or public presentation for disquiet to be removed.

\footnotetext{
${ }^{2}$ The position with Assemblies of God in the United States is different. Ministers there are required to renew their credentials annually and to fill in a detailed questionnaire about doctrinal distinctives. Where they disagree with these distinctives, a written explanation is required. Ministers are required to agree that 'speaking with tongues is the initial physical evidence of the baptism in the Holy Spirit'.
} 


\section{METHOD}

The study reported on here makes use of a postal survey by questionnaire.

The research was carried out in the United Kingdom where the two largest Pentecostal denominations are the Assemblies of God and the Elim Pentecostal Church. Both of these denominations publishes an annual yearbook listing its ordained clergy. Both distinguishe between ministers who work in the UK and missionaries who work overseas. For the purposes of this study, overseas workers were excluded. All other workers, active, retired, itinerant and pastoral were included.

Although both denomination makes use of a different governmental structure, there are broad similarities between their operations. Assemblies of God and Elim each elect an Executive Council which has a national authority. Both these Executive Councils were approached and asked to give written support to the survey. This they did and a letter endorsing the questionnaire, and signed by the Chairman of each Council was mailed with the questionnaire along with a freepost return envelope. Each questionnaire was completed anonymously, but was identifiable by means of a numerical code. This allowed follow-up letters to be sent to ministers who failed to respond. A second follow-up letter was sent out to those who did not respond to the first and replacement questionnaire were offered to those who had mislaid them. Finally, a telephone follow-up was used to selected ministers who had still not replied. This procedure led to 401 usable questionnaires from Assemblies of God ministers, a response rate of $57 \%$, and 367 usable questionnaires from Elim ministers, a response rate of $64 \%$.

The total sample comprised $768(97.4 \%)$ males, $23(2.3 \%)$ females and 2 persons of undeclared sex. There were $216(28 \%)$ respondents aged under 39, $496(65 \%)$ aged between 40 and $64,53(7 \%)$ over 65 years, and 3 of undeclared age. The sample, then, was predominantly male and middle aged.

As part of a lengthy questionnaire which was anonymously answered, the ministers were presented with 118 Likert-style statements on doctrinal, social and ecclesiological matters. Ministers were asked to say whether they 'agreed strongly', 'agreed', were 'not certain', 'disagreed' or 'disagreed strongly' with the statements. The four statements given below are the focus of this paper.

Data were analysed by SPSS 6.1 for Windows, Network version, (Norussis, 1993).

\section{RESULTS}

Analysis of variance comparisons were made between Elim and British Assemblies of God ministers in their responses to each of the three statements. It was found that there was a significant difference in respect of the statement, 'Speaking with tongues is necessary as initial evidence of the baptism in the Holy Spirit' $(F=189.06, p<.000)$ and a significant difference in respect of the statement, 'Baptism in the Spirit can occur without speaking with tongues' $(\mathrm{F}=185.60, \mathrm{p}<.000)$, but no difference was found either for, 'The baptism in the Holy Spirit is evidenced by "signs following" ( $F=2.24$, NS) or for "I believe there is a distinct Christian experience which might be called "the baptism in the Spirit" ( $F=0.387$, NS). A breakdown of response frequencies is shown in tables 1 and 2 . 


\section{DISCUSSION}

Tables 1 and 2 show what British Assemblies of God and Elim ministers, answering anonymously, believe about matters in their denominational fundamental truths. Table 1 shows that $2 \%$ of British Assemblies of God ministers either do not believe or are uncertain that there is a distinct Christian experience that may be called 'the baptism in the Spirit'. The table also shows $11 \%$ disagree with their denominational position on tongues as the initial evidence and a further $8 \%$ are uncertain on this matter.

The figure in table 1 showing that $30 \%$ of these ministers believe that baptism in the Spirit can occur without speaking with tongues need not, in the context of British Assemblies of God, be taken as direct disagreement with denominational fundamental truths. Agreement with this statement may suggest circumstances can be envisaged where baptism in the Spirit takes place but where the receiver fails to speak in tongues at the time. Such circumstances are often predicated on the supposition that the receiver could have spoken in tongues and failed to do so because of a misunderstanding of the nature of the experience.

The figure showing that $8 \%$ of these ministers disagree that the baptism in the Spirit is evidenced by 'signs following' implies that the baptism in the Spirit has no physical accompaniment.

Table 2 shows that $3 \%$ of Elim ministers either do not believe or are uncertain that there is a distinct Christian experience that may be called 'the baptism in the Spirit'. The table also shows that $4 \%$ of Elim ministers disagree with their denominational position on the evidence for the baptism in the Spirit and a further 5\% are uncertain on the matter.

The figure in table 2 showing that $73 \%$ of these ministers believe that the baptism in the Spirit can occur without speaking in tongues is, in the context of the Elim position, probably best understood as showing that the evidence for the baptism in the Spirit is a 'sign following' but not necessarily tongues.

When the two tables are considered together to see what they say about the possibility of unity between British Assemblies of God and Elim they show that (a) $42 \%$ of Elim ministers accept the tight Assemblies of God position on tongues as initial evidence and (b) $30 \%$ of British Assemblies of God ministers (who believe that baptism in the Spirit can occur without speaking in tongues) might be willing to accept the Elim position. Moreover, there is overwhelming agreement (88\% from British Assemblies of God and 91\% from Elim) that some form of evidence or 'sign following' should be consequent upon the baptism in the Spirit. There is therefore a clear overlap between the ministers as well as a clear distinction between them.

\section{CONCLUSION}

On the positive side this survey shows how closely and frequently the majority of ministers agree with their own denomination's distinctive teaching about the baptism in the Holy Spirit. It also shows that there is a large measure of agreement between the two largest Pentecostal denominations in Britain. On the negative side the survey shows that between $9 \%$ and $12 \%$ of Pentecostal ministers appear to reject a doctrine that ties the baptism in the Spirit to any physical manifestation, and that between $2 \%$ and $3 \%$ reject the distinctiveness of the very experience which historically led to the formation of Pentecostal denominations. Together these findings raise a set of questions about the role of ministerial training and accreditation 
within Pentecostal denominations and a further set of questions about the extent to which the distinctives of Pentecostal congregations are likely to be maintained when a measurably proportion of ministers fail to hold to a doctrinal position originally deemed to be fundamental.

\section{ACKNOWLEDGEMENT}

I am grateful to Revd Desmond Cartwright for explaining, with historical detail, the Elim position on evidence for the baptism in the Spirit and to Dr Calvin Holsinger for explaining, with contemporary detail, the current position of American Assemblies of God on ministerial accreditation. 


\section{BIBLIOGRAPHY}

Allen, D (1987), The Premillennial Return of Christ. Paper read at the 1987 Assemblies of God General Conference, Minehead.

Canty, G (1987), The Practice of Pentecost, London, Hodder and Stoughton.

Kay, W K (1989), A History of British Assemblies of God, doctoral dissertation, University of Nottingham, published with minor changes as Inside Story, Lifestream/Mattersey Hall Publishing, 1990.

Kay, W K (1997) Distinctive Continuity and Distinctive Change, in K Warrington (ed) Pentecostal Perspectives, Carlisle, Paternoster.

McGee G B (1991), Initial Evidence, Peabody, Mass, Hendrickson Publishers.

Norussis M (1993), SPSS for Windows: base system user's guide: release 6.0, Chicago, SPSS Inc.

Walker, T W (1976), The Baptism in the Holy Spirit, in P S Brewster (ed) Pentecostal Doctrine, Cheltenham, Elim Pentecostal Church Headquarters. 


\section{Table 1}

\section{Assemblies of God}

\begin{tabular}{lccc}
\hline & $\begin{array}{c}\text { Disagree } \\
\frac{0}{0}\end{array}$ & $\begin{array}{c}\text { Not Certain } \\
\frac{0}{0}\end{array}$ & $\begin{array}{c}\text { Agree } \\
\frac{0}{0}\end{array}$ \\
\hline $\begin{array}{l}\text { I believe there is a distinct } \\
\text { Christian experience which might be } \\
\text { called 'the baptism in the Spirit' }\end{array}$ & 1 & 1 & 98 \\
$\begin{array}{l}\text { Speaking with tongues is necessary } \\
\text { as initial evidence of the baptism } \\
\text { in the Holy Spirit }\end{array}$ & 11 & 8 & 81 \\
$\begin{array}{l}\text { Baptism in the Spirit can occur } \\
\text { without speaking with tongues }\end{array}$ & 57 & 13 & 30 \\
$\begin{array}{l}\text { The baptism in the Holy Spirit is } \\
\text { evidenced by 'signs following' }\end{array}$ & 8 & & \\
\end{tabular}

\section{Table 2}

\section{Elim}

\begin{tabular}{|c|c|c|c|c|}
\hline & $\begin{array}{c}\text { Disagree } \\
\frac{\circ}{0} \\
\end{array}$ & Not & $\begin{array}{l}\text { Certain } \\
\frac{\circ}{0}\end{array}$ & $\begin{array}{c}\text { Agree } \\
\frac{\circ}{0}\end{array}$ \\
\hline I believe there is a distinct & & & & \\
\hline $\begin{array}{l}\text { Christian experience which might be } \\
\text { called 'the baptism in the spirit' }\end{array}$ & 1 & & 2 & 97 \\
\hline $\begin{array}{l}\text { Speaking with tongues is necessary } \\
\text { as initial evidence of the baptism } \\
\text { in the Holy Spirit }\end{array}$ & 49 & & 9 & 42 \\
\hline $\begin{array}{l}\text { Baptism in the Spirit can occur } \\
\text { without speaking with tongues }\end{array}$ & 18 & & 9 & 73 \\
\hline $\begin{array}{l}\text { The baptism in the Holy Spirit is } \\
\text { evidenced by 'signs following' }\end{array}$ & 4 & & 5 & 91 \\
\hline
\end{tabular}

'Agree strongly' and 'agree' categories are collapsed. Similarly 'disagree strongly' and 'disagree' categories. 